\title{
Antiimplantation activity of the ethanolic root extract of Momordica cymbalaria Fenzl in rats
}

\author{
Raju Koneri, C.D. Saraswati*, R. Balaraman*, E.A. Ajeesha*
}

\begin{abstract}
Visveswarapurastiteof
Visveswarapura Institute of Pharmaceutical Sciences, $25^{\text {th }}$ main, Banashankari $2^{\text {nd }}$ Stage Bangalore - 560070, *Department of Pharmacy, Faculty of Technology and Engineering, M. S. University of Baroda, Baroda, India

Received: 3.8.2006

Revised: 12.10 .2006

Accepted: 26.11.2006

Correspondence to: Raju Koneri E-mail: rajukoneri@rediffmail.com
\end{abstract}

\begin{abstract}
O bjective: To evaluate the antiimplantation activity of the ethanolic root extract of Momordica cymbalaria Fenzl.

Materials and Methods: The acute oral toxicity study was performed according to the OPPTS guidelines. The ethanolic root extract was investigated for antiimplantation, estrogenic and progestrogenic activities at doses of 250 and $500 \mathrm{mg} / \mathrm{kg}$ body weight. Antiimplantation activity was studied on successive stages of embryogenesis. Estrogenic studies were carried out by examining uterine weight, histoarchitecture of uterus, vaginal cornification, uterine content of glucose, cholesterol and alkaline phosphatase levels in immature rats. Progestrogenic activity assay was performed by pregnancy maintenance in rats and Clauberg's test (endometrial proliferation assay) in immature rabbits.
\end{abstract}

Results: Both doses of the ethanolic root extract exhibited highly significant $(P<0.001)$ antiimplantation activity. However, an investigation of the estrogenic activity did not show any increase in uterine weight or vaginal cornification. The histoarchitecture (uterotrophic changes) such as thickness of endometrium and height of endometrial epithelium was unaltered in treated rats. There were no increases in the uterine content of glucose, cholesterol or alkaline phosphatase levels when compared with the control group. Pregnancy was not maintained in the pregnancy maintenance test for progestrogenic activity. Uterine proliferation was not seen in Clauberg's test (endometrial proliferation assay) for progestrogenic activity in immature rabbits.

Conclusion: The ethanolic root extract of Momordica cymbalaria Fenzl exhibited antiimplantation activity but this is not due to estrogenic or progestrogenic activities.

\section{KEY WORDS: Antiimplantation, estrogenic, Momordica cymbalaria, progestrogenic}

The use of plant preparations and extracts for their antifertility properties has a long-standing history among Indian physicians. The aqueous and ethanolic extracts and dried forms of fruits and leaves of Momordica cymbalaria Fenzl. (Cucurbitaceae) have been shown to have antidiabetic and hypolipidemic properties..$^{[1-3]}$ The roots of the plant are used for menstrual irregularities, antifertility, antiovulatory and abortifacient activities. ${ }^{[4,5]}$ Other plants like Momordica charantia, Momordica dioca etc. of the Cucurbitaceae family also have well-established antifertility activity. ${ }^{[4]}$ Our earlier study ${ }^{[5]}$ has demonstrated antifertility and antiovulatory potential of roots of Momordica cymbalaria. However, no detailed studies have been undertaken with reference to its antiimplantation property. Hence, we have undertaken this study to evaluate the antiimplantation activity of Momordica cymbalaria Fenzl.

\section{Materials and Methods}

The fresh roots of Momordica cymbalaria Fenzl were collected from Gadag district, Karnataka and identified and authenticated by Dr. Sreenath, Department of Botany, Bangalore University, Bangalore. A specimen sample of the same was preserved in the herbarium of the Department of Botany, Bangalore University, Bangalore, with voucher no. 18122003 for future reference.

The roots of Momordica cymbalaria were isolated, chopped into small pieces, dried in the shade at room temperature for seven days and powdered. The powder was extracted with ethyl alcohol to get a yield of $14.1 \% \mathrm{w} / \mathrm{w}$ of the ethanolic root extract.

Colony-bred female albino Wistar rats (150-200 g) were 
maintained under controlled standard animal house conditions with ad libitum access to food and water.

They were fed with standard rat feed (Amrut rat and mice feed, Pranav agro industries Ltd. Sangli, India). All the experiments were performed according to the CPCSEA norms after obtaining the approval of the institutional animal ethics committee (IAEC). The oral acute toxicity study was performed using the up and down procedure (OPPTS guidelines). ${ }^{[5]}$

Antiimplantation activity: Antiimplantation activity was determined as described by Khanna and Chowdary. ${ }^{[6]}$ Colonybred female albino Wistar rats of proven fertility (150-200 g) were maintained under controlled standard animal house conditions with ad libitum access to food and water. Vaginal smears from each rat were monitored daily. Only rats with normal estrous cycle $^{[7]}$ were selected for the experiment. The female rats were caged with male rats of known fertility in the ratio of $2: 1$ in the evening of proestrous and examined the following morning for evidence of copulation. Female rats exhibiting the copulation plug or thick clump of spermatozoa in their vaginal smears were separated and that day was designated as day one of pregnancy. Pregnant rats were divided into five groups, each group containing six animals. Group I received vehicle only (Tween 80, 1\%) and Groups II and III received the ethanolic root extract at 250 and $500 \mathrm{mg} / \mathrm{kg}$ body weight doses respectively from days one to seven of pregnancy. Groups IV and V received the ethanolic root extract at 250 and $500 \mathrm{mg} / \mathrm{kg}$ body weight doses for three days from days one to three of pregnancy to assess antizygotic activity. ${ }^{[8]}$ Groups VI and VII received the ethanolic extract at 250 and $500 \mathrm{mg} / \mathrm{kg}$ body weight on days four and five of pregnancy to assess blastocystotoxic activity. ${ }^{[8]}$ Groups VIII and IX received the ethanolic root extract at 250 and $500 \mathrm{mg} / \mathrm{kg}$ on days six, seven, eight and nine of pregnancy to detect early abortifacient activity. ${ }^{[8]}$ All these treatments were given orally. The rats were laprotamized under light ether anesthesia and semisterile conditions on day ten of pregnancy and the number of implantation sites were recorded.

Estrogenic and antiestrogenic activities: Estrogenic and antiestrogenic activities were determined as described by Badmi et al. ${ }^{[9]}$ Colony-bred female albino Wistar rats, each 2123 days old and weighing 35-45 g (immature rats) were used. Animals were randomly divided into six groups, each group consisting of six animals. Group I received vehicle only (Tween 80, 1\%) and served as control. Group II received ethinyl estradiol dissolved in olive oil s.c. at a dose of $1 \mu \mathrm{g} / \mathrm{rat}$. Groups III and IV received ethanolic root extract at 250 and $500 \mathrm{mg} / \mathrm{kg}$ body weight doses. Groups V and VI received ethanolic root extract at 250 and $500 \mathrm{mg} / \mathrm{kg}$ body weight doses and ethinyl estradiol (s.c, $1 \mu \mathrm{g} / \mathrm{rat}$ ). All the above treatments were given orally for seven days. On the eighth day, the rats were sacrificed and the uteri were dissected out, surrounding tissues removed, blotted on filter paper and weighed quickly on a sensitive balance (Precisa, XB series). A portion of the uterine tissues from control and treated animals were fixed in 10\% formalin buffer for 24 $\mathrm{h}$, dehydrated in alcohol and then embedded in paraffin. The paraffin blocks were sectioned at $5 \mu \mathrm{m}$ intervals and stained with haematoxylin-eosin for histological examinations. The sections were examined under digital microscope (Labomed). Diameter of uterus, thickness of endometrium and height of endometrial epithelium were measured with the help of digital microscope software. The other portion of the uterus was homogenized in ice-cold distilled water. The homogenate was centrifuged at $3000 \mathrm{rpm}$ for $15 \mathrm{~min}$ and the supernatant was used for the estimation of glucose, cholesterol and alkaline phosphatase levels using diagnostic kits (Autospan, Span diagnostics Ltd.).

\section{Progestational and antiprogestational activities}

Pregnancy maintenance test: Progestational activity was assessed by the pregnancy maintenance test as described by Vogal. ${ }^{[10]}$ Mature female Sprague Dawley (SD) rats were inseminated by placing them with male rats overnight in the ratio of $2: 1$. On the eighth day of pregnancy, the females were ovariectomized. Then, the drug was administered as follows: Group I received Tween 80, 1\% (p.o. daily) from the eighth to the 19th day of pregnancy and served as the control; Group II received progesterone $3 \mathrm{mg} / \mathrm{rat} /$ day s.c, from the eighth to the 19th day and served as a reference standard; Groups III and IV received the ethanolic root extract of Momordica cymbalaria Fenzl at doses of 250 and $500 \mathrm{mg} / \mathrm{kg}$ (p.o. daily) from the eighth to the $19^{\text {th }}$ day. Estradiol $1 \mu \mathrm{g} / \mathrm{rat} /$ day was administered concomitantly with the test compound. On the $20^{\text {th }}$ day, the animals were autopsied and the presence or absence of implantation sites and numbers of live embryos were recorded.

Clauberg's test: Progestational and antiprogestational activities were assessed in rabbits using Clauberg's assay as described by Vogal. ${ }^{[10]}$ Immature female rabbits each weighing 550-650g were maintained under standard experimental conditions. The animals were randomly assigned to six groups of six animals per group. All animals were injected subcutaneously with estradiol valerate at the dose of $8.3 \mu \mathrm{g} / \mathrm{kg}$ daily for a period of six days. After estrogen priming, they were treated as follows: Group I received $0.5 \%$ gum acacia solution $10 \mathrm{ml} / \mathrm{kg}$ (p.o. daily) for five days; Groups II and III received the ethanolic root extract of Momordica cymbalaria Fenzl. at doses of 250 and $500 \mathrm{mg} / \mathrm{kg}$ (p.o. daily) for five days; Group IV received norethisterone $0.75 \mathrm{mg} / \mathrm{kg}$ (p.o daily) for five days; Groups V and VI received norethesterone $0.75 \mathrm{mg} / \mathrm{kg}$ and the ethanolic root extract of Momordica cymbalaria Fenzl, at doses of 250 and $500 \mathrm{mg} / \mathrm{kg}$ (p.o. daily) for five days. The animals were sacrificed on the 12th day. The uterus was dissected out, adherent tissues were removed, blotted on a filter paper and was preserved in the neutral formalin buffer $10 \%$ for $24 \mathrm{~h}$, then dehydrated in alcohol and embedded in paraffin wax. Sections of $5 \mu \mathrm{m}$ were cut and stained with haematoxylin-eosin and examined under digital microscope (labomed).

Statistical Analysis: The data was analyzed using one way ANOVA followed by the Tukey-Kramer multiple comparison posttest. A $P$ value $\leq 0.05$ was considered to be statistically significant.

\section{Results}

No mortality was seen in the acute toxicity test at doses up to $5000 \mathrm{mg} / \mathrm{kg}$. Therefore, we selected $1 / 10^{\text {th }}$ and $1 / 20^{\text {th }}$ of this dose as doses for the study (500 and $250 \mathrm{mg} / \mathrm{kg}$ ).

Antiimplantation activity: The ethanolic root extract at 250 and $500 \mathrm{mg} / \mathrm{kg}$ body weight doses exhibited highly significant ( $P$ $<0.001$ ) antiimplantation activity. Both doses of the extract also showed significant antiimplantation activity when administered 
on days 1-3 (antizygotic activity), days 4 and 5 (blastocystotoxic activity) and days 6-9 (early abortifacient activity) [Table 1].

Estrogenic and antiestrogenic activities: Administration of the ethanolic root extract in rats at doses of 250 and $500 \mathrm{mg} / \mathrm{kg}$ did not show any increase in the uterine weight. The ethinyl estradiol group (group II) showed a highly significant $(P<0.001)$ increase in uterine weight [Table 2]. The vagina remained closed and cornification was not induced in the control or ethanolic extract-treated groups whereas the ethinyl estradiol group showed vaginal opening and cornification of cells [Table 3]. Hence, the ethanolic root extract being studied is not estrogenic in nature at either of the doses. Conjoint administration of ethinyl estradiol and the ethanolic extract at doses of 250 and $500 \mathrm{mg} / \mathrm{kg}$ body weight did not show any decrease in the uterine weight when compared with the ethinyl estradiol group [Table 2]. The histoarchitecture (uterotrophic changes) such as thickness of the endometrium and height of the endometrial epithelium in treated rats at 250 and $500 \mathrm{mg} / \mathrm{kg}$ body weight doses were similar to that of control, whereas ethinyl estradiol showed highly significant uterotrophic changes [Table 2, Figures 1-4]. Conjoint administration of ethinyl estradiol and the ethanolic root extract at doses of 250 and $500 \mathrm{mg} / \mathrm{kg}$ body weight showed no uterotrophic changes when compared with the ethinyl estradiol group [Table 2, Figures 5-6]. The ethanolic extract at doses 250 and $500 \mathrm{mg} / \mathrm{kg}$ body weight did not show any increase in the uterine content of glucose, cholesterol and alkaline phosphatase when compared with the control group [Table 3]. However, the ethinyl estradiol group showed a significant $(P<$ 0.05) increase in the uterine content of glucose, cholesterol and alkaline phosphatase which was similar to the ueterine contents seen with conjoint administration of the ethanolic root extract and ethinyl estradiol [Table 3]

Progestational and antiprogestational activities: Pregnancy was maintained by administration of estradiol $0.1 \mu \mathrm{g} / \mathrm{rat} / \mathrm{day}$ s.c. and progesterone $3 \mathrm{mg} / \mathrm{rat} /$ day s.c. for 13 days to the rats that were ovarietomized on the eighth day of pregnancy. The number of viable fetuses seen at the time of autopsy (on the $20^{\text {th }}$ day) and the net success index of pregnancy maintenance was statistically significant $(P<0.001)$ in the rats receiving estradiol and progesterone when compared to the animals in the control group [Table 4]. Animals in the control group had complete abortion and pregnancy was not maintained. Administration of estradiol $0.1 \mu \mathrm{g} / \mathrm{rat} /$ day and the ethanolic root extract of Momordica cymbalaria Fenzl at doses of 250 and $500 \mathrm{mg} / \mathrm{kg} / \mathrm{day}$ to the rats did not maintain pregnancy [Table 4].

Claugerg's assay: Administration of estrogen and the ethanolic root extract of Momordica cymbalaria Fenzl at 250 and $500 \mathrm{mg} / \mathrm{kg}$ doses showed ramification of the uterus but not proliferation [Figure 8]. Administration of estrogen and norethisterone showed medium proliferation of endometrium

\section{Table 1}

Effect of ethanolic root extract of Momordica cymbalaria on implantation in rats at different stages of pregnancy

\begin{tabular}{|c|c|c|c|c|}
\hline Treatment & Days of administration & $\begin{array}{l}\text { No. of rats without } \\
\text { implantation sites on day } 10\end{array}$ & No. of implantation sites & $\begin{array}{l}\% \text { of rats without } \\
\text { implantation sites on day } 10\end{array}$ \\
\hline $\begin{array}{l}\text { Control } \\
\text { (Tween } 80 \text { 1\%) }\end{array}$ & 1 to 7 & 0 & $10.8 \pm 0.94$ & 0 \\
\hline Ethanolic extract & 1 to 7 & 6 & $0^{*}$ & 100 \\
\hline \multirow[t]{3}{*}{$250 \mathrm{mg} / \mathrm{kg}$} & 1 to 3 & & $2.6 \pm 1.35^{\star *}$ & 50 \\
\hline & 4 and 5 & & $0^{*}$ & 100 \\
\hline & 6 to 9 & 3 & $3 \pm 1.61^{\star *}$ & 50 \\
\hline Ethanolic extract & 1 to 7 & 6 & $0^{*}$ & 100 \\
\hline \multirow[t]{3}{*}{$500 \mathrm{mg} / \mathrm{kg}$} & 1 to 3 & 4 & $2.16 \pm 1.51^{* *}$ & 66.6 \\
\hline & 4 and 5 & 5 & $1.66 \pm 1.66^{* *}$ & 83.3 \\
\hline & 6 to 9 & 4 & $1.83 \pm 1.32^{* *}$ & 66.6 \\
\hline
\end{tabular}

Values are mean \pm SE (standard error), $n=6$, ${ }^{\star} P<0.001$ when compared with control, ${ }^{* \star} P<0.01$ when compared with control

\section{Table 2}

Histological changes in the uterus and endometrium after treatment with the ethanolic root extract of Momordica cymbalaria

\begin{tabular}{|c|c|c|c|}
\hline Treatment (dose, $\mathrm{mg} / \mathrm{kg}$ body weight) & $\begin{array}{l}\text { Diameter of uterus }(\mathrm{mm}) \\
\text { H\&E } 40 \mathrm{x}\end{array}$ & $\begin{array}{l}\text { Thickness of endometrium } \\
(\mu \mathrm{m}) \mathrm{H \& E} 100 \mathrm{x}\end{array}$ & $\begin{array}{l}\text { Height of endometrial epithelium } \\
\qquad(\mu \mathrm{m}) \mathrm{H \& E} 100 \mathrm{x}\end{array}$ \\
\hline Control (Tween 80, 1\%) & $0.50 \pm 0.09$ & $17.58 \pm 0.3$ & $165.31 \pm 2.26$ \\
\hline Ethinyl estradiol ( $1 \mu \mathrm{g} / \mathrm{rat})$ & $1.36 \pm 0.04^{*}$ & $37.65 \pm 1.04^{*}$ & $352.78 \pm 5.44^{*}$ \\
\hline Ethanolic extract $(250 \mathrm{mg} / \mathrm{kg})$ & $0.49 \pm 0.008$ & $17.85 \pm 0.31$ & $166.48 \pm 1.62$ \\
\hline Ethanolic extract $(500 \mathrm{mg} / \mathrm{kg})$ & $0.51 \pm 0.02$ & $17.71 \pm 0.21$ & $164.18 \pm 2.82$ \\
\hline \multicolumn{4}{|l|}{ Ethinyl estradiol (1 mcg/rat) + } \\
\hline ethanolic extract $(250 \mathrm{mg} / \mathrm{kg})$ & $1.37 \pm 0.02$ & $38.68 \pm 1.31$ & $348.35 \pm 5.53$ \\
\hline \multicolumn{4}{|l|}{ Ethinyl estradiol (1 mcg/rat)+ } \\
\hline ethanolic extract $(500 \mathrm{mg} / \mathrm{kg})$ & $1.31 \pm 0.03$ & $38.68 \pm 1.31$ & $348.35 \pm 5.53$ \\
\hline
\end{tabular}

Values are mean \pm SE (standard error), $n=6$. ${ }^{*} P<0.001$ when compared with control 
Estrogenic and antiestrogenic activities of the ethanolic root extract of Momordica cymbalaria

\begin{tabular}{|c|c|c|c|c|c|}
\hline $\begin{array}{l}\text { Treatment } \\
\text { (dose, } \mathrm{mg} / \mathrm{kg} \text { body weight) }\end{array}$ & $\begin{array}{l}\text { Uterine weight } \mathrm{mg} / \\
100 \mathrm{~g} \text { body weight }\end{array}$ & $\begin{array}{c}\text { Vaginal } \\
\text { cornification }\end{array}$ & $\begin{array}{l}\text { Glucose } \mathrm{mg} / \\
100 \mathrm{mg} \text { of uterus }\end{array}$ & $\begin{array}{l}\text { Cholesterol mg/ } \\
100 \mathrm{mg} \text { of uterus }\end{array}$ & $\begin{array}{l}\text { Alkaline phosphatase } \\
\text { IU/100 mg of uterus }\end{array}$ \\
\hline Control (Tween 80, 1\%) & $39.31 \pm 0.53$ & Vagina not open & $0.33 \pm 0.02$ & $0.60 \pm 0.09$ & $0.26 \pm 0.02$ \\
\hline Ethinyl estradiol ( $1 \mu \mathrm{g} / \mathrm{rat})$ & $130.51 \pm 9.79^{*}$ & Open $(+++)$ & $0.43 \pm 0.03^{*}$ & $0.95 \pm 0.07^{*}$ & $0.34 \pm 0.04^{*}$ \\
\hline Ethanolic extract $(250 \mathrm{mg} / \mathrm{kg})$ & $36.66 \pm 3.08$ & Vagina not open & $0.33 \pm 0.01$ & $0.49 \pm 0.24$ & $0.21 \pm 0.04$ \\
\hline Ethanolic extract $(500 \mathrm{mg} / \mathrm{kg})$ & $39.56 \pm 1.95$ & Vagina not open & $0.34 \pm 0.03$ & $0.55 \pm 0.16$ & $0.24 \pm 0.01$ \\
\hline $\begin{array}{l}\text { Ethinyl estradiol }(1 \mu \mathrm{g} / \mathrm{rat})+ \\
\text { ethanolic extract }(250 \mathrm{mg} / \mathrm{kg})\end{array}$ & $134.14 \pm 3.41$ & Open $(+++)$ & $0.38 \pm 0.07$ & $0.85 \pm 0.03$ & $0.33 \pm 0.02$ \\
\hline $\begin{array}{l}\text { Ethinyl estradiol }(1 \mu \mathrm{g} / \mathrm{rat})+ \\
\text { ethanolic extract }(500 \mathrm{mg} / \mathrm{kg})\end{array}$ & $129.43 \pm 6.68$ & Open $(+++)$ & $0.37 \pm 0.03$ & $0.83 \pm 0.06$ & $0.30 \pm 0.03$ \\
\hline
\end{tabular}

Values are mean \pm SE (standard error), $n=6 .+++=$ cornified cells. ${ }^{*} P<0.001$ when compared with control

\section{Table 4}

Effect of ethanolic root extract of Momordica cymbalaria, Fenzl. on the maintenance of pregnancy in the rats ovariectomized on the $8^{\text {th }}$ day of pregnancy

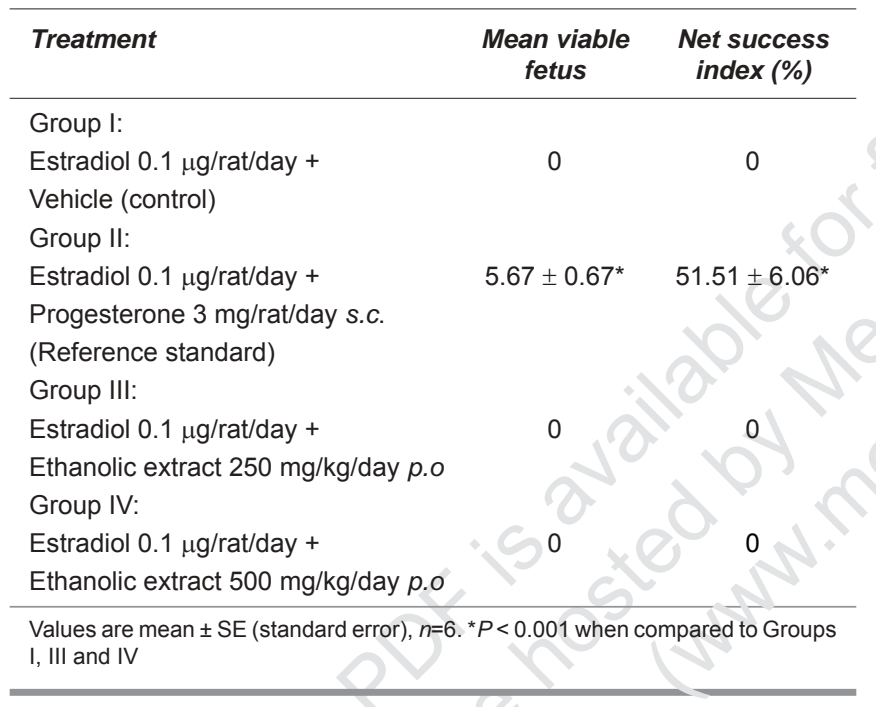

and endometrial glands [Figure 9]. However, administration of estrogen, norethisterone and the ethanolic root extract of Momordica cymbalaria Fenzl did not inhibit the proliferate changes caused by norethisterone [Figure 10].

Statistical analysis: The results have been expressed as mean \pm SE (standard error). The statistical significance between groups was analyzed using one-way ANOVA test and Tukey-Kramer multiple comparison postest and $P$ value $\leq 0.05$ was considered statistically significant.

\section{Discussion}

Our earlier study ${ }^{|5|}$ had demonstrated antiovulatory and abortifacient potential of the roots of Momordica cymbalaria. Inhibition of ovulation may be because of hormonal manipulation and may be the cause for the antifertility activity of the roots in the postcoital state of rats. Significant abortifacient potential of the roots may also be due to the antifertility activity. Hence, the present study is designed to investigate the antifertility activity and the involvement of estrogenic and progestrogenic mechanisms in the antiimplantation activity of the roots of Momordica cymbalaria. The extract has shown highly significant antiimplantation activity when it was administered from days 1 to 7 . The extract was also given during different periods of gestation on successive stages of embryogenesis as described by Hafez. ${ }^{|8|}$ From our results, it is evident that the extract inhibits implantation when given at the zygotic stage (days 1-3) and the blastocyst stage (days 3-5). ${ }^{[11]}$ Similar activity is reported in many plants. ${ }^{[12]}$ Many antifertility plant extracts are known to exhibit estrogenic activity in rats ${ }^{|13|}$ Estrogen causes an increase in protein synthesis, uterine weight, water uptake and retention of fluid leading to ballooning of the uterus. ${ }^{[14]}$ In addition, estrogen also induces uterotrophic changes such as increase in diameter of the uterus, thickness of endometrium, height of endometrial epithelium, providing nonreceptive conditions for implantation. ${ }^{[15]}$ Estrogen causes vaginal opening, which is a qualitative measure of estrogen potency. Presence of cornified cells in vaginal smears also indicates estrogen activity. Estrogen is known to increase uterine content of glucose, cholesterol, glycogen and alkaline phosphatase, thereby changing the uterine milieu and creating nonreceptive conditions in the uterus. ${ }^{[14]}$ Administration of the ethanolic root extract of Momordica cymbalaria Fenzl to immature rats at doses of 250 and $500 \mathrm{mg} / \mathrm{kg}$ did not show any change in uterine weight or histoarchitecture of uterus (uterotrophic changes) such as diameter of the uterus, thickness of endometrium or height of endometrial epithelium. There was no vaginal opening or presence of cornified cells in the vaginal smear. The treatment also did not show any change in the uterine content of glucose, cholesterol and alkaline phosphatase when compared with control group. Conjoint administration of ethanolic extract with ethinyl estradiol did not decrease the uterine weight and histoarchitecture of uterus (uterotrophic changes) when compared with ethinyl estradiol. The ethanolic root extract itself also did not cause any decrease in the uterine content of glucose, cholesterol and alkaline phosphatase. Hence, neither dose of the ethanolic extract has any estrogenic or antiestrogenic activities.

Pregnancy maintaince test and Clauberg's assay are commonly used in the bioassay for progestational activity..$^{10,16-18]}$ 
Figure 1: Section of immature rat uterus treated with Tween $801 \%$ (control) (H\&E, 100x), n=6

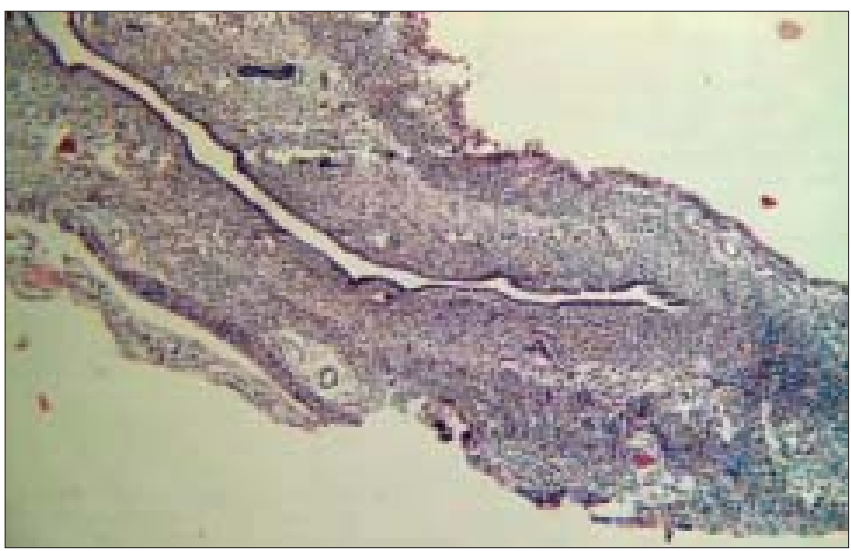

Figure 2: Section of immature rat uterus treated with ethinyl estradiol (s.c, $1 \mu \mathrm{g} / \mathrm{rat}$ ). (H\&E, 100x), $\mathrm{n}=6$

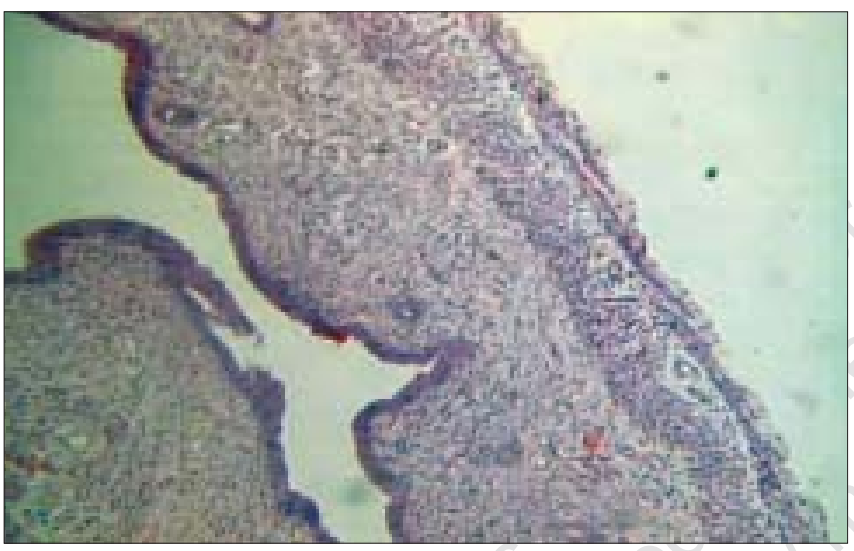

Figure 3: Section of immature rat uterus treated with ethanolic root extract $(250 \mathrm{mg} / \mathrm{kg})(\mathrm{H} \& \mathrm{E}, 100 \mathrm{x}), \mathrm{n}=6$

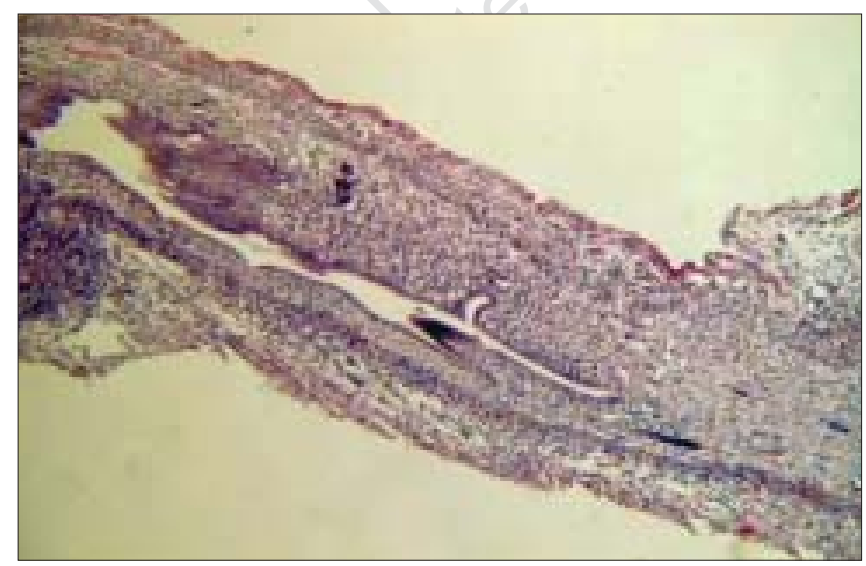

Bilateral ovariectomy performed in rats during the first half of pregnancy results in termination of gestation, but if ovariectomy is performed during the second half of pregnancy, abortion may not necessarily occur. This is due to the capacity of the placenta
Figure 4: Section of immature rat uterus treated with ethanolic root extract $(500 \mathrm{mg} / \mathrm{kg})$. (H\&E, 100x), $\mathrm{n}=6$
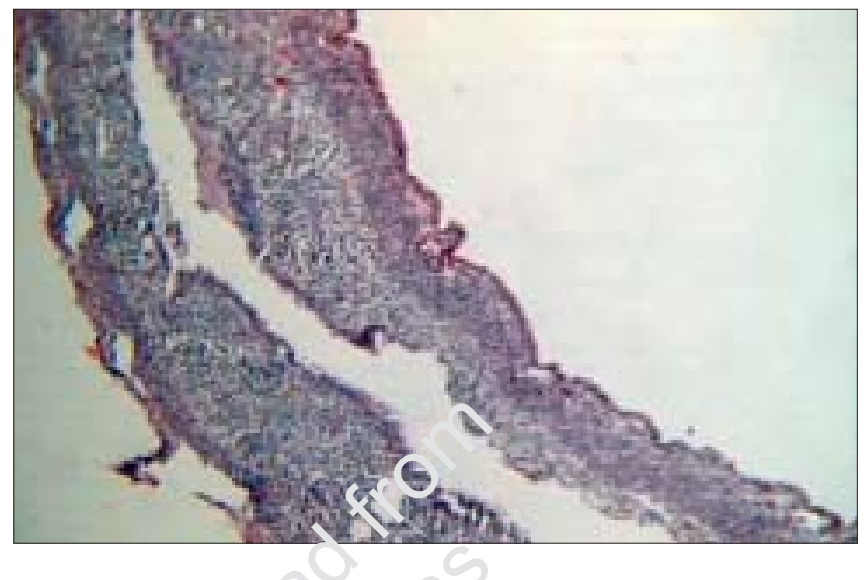

Figure 5: Section of immature rat uterus treated with ethanolic root extract $(250 \mathrm{mg} / \mathrm{kg})$ and Ethinyl estradiol (s.c, $1 \mu \mathrm{g} / \mathrm{rat})$. (H\&E, 100x), $n=6$

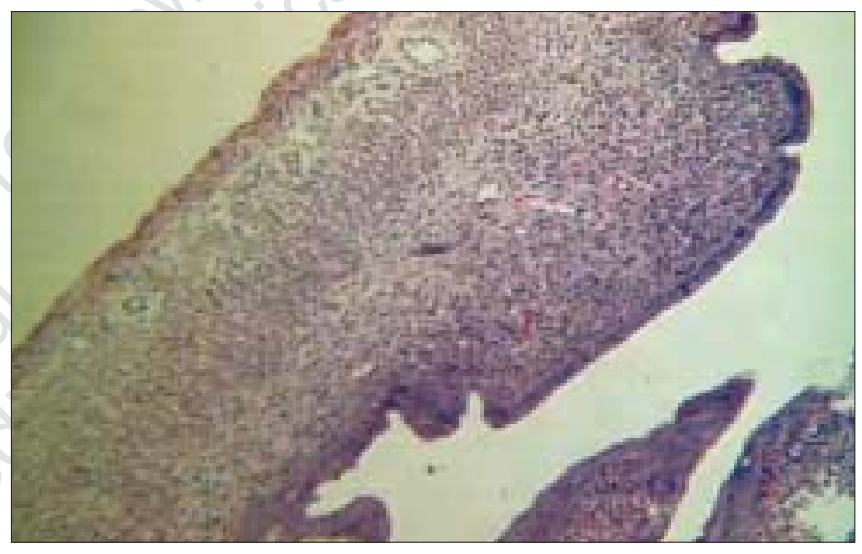

Figure 6: Section of immature rat uterus treated with ethanolic extract $(500 \mathrm{mg} / \mathrm{kg})$ and Ethinyl estradiol (s.c, $1 \mu \mathrm{g} / \mathrm{rat})$.(H\&E, 100x), n=6

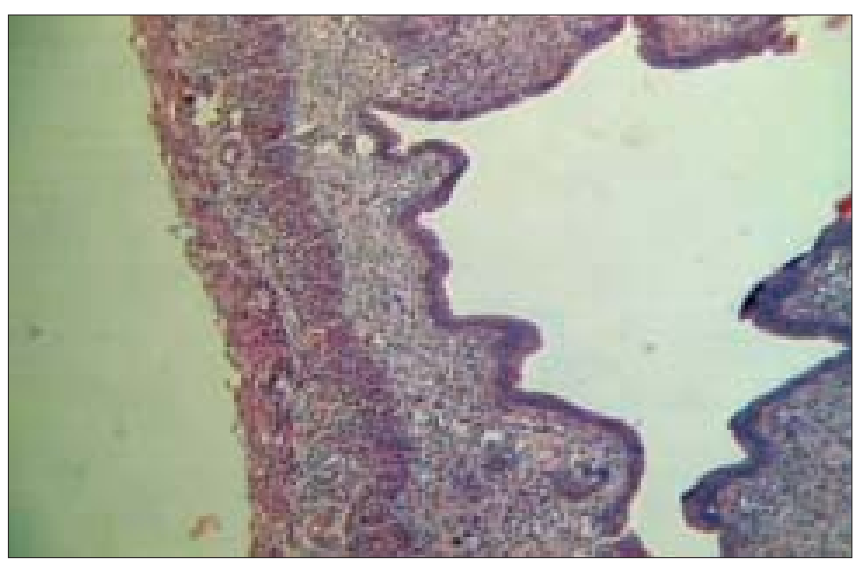

to produce progesterone and estrogen. It has been shown that pregnancy can be successfully maintained in rats ovariectomized during the first half of pregnancy by administration of sufficient quantities of exogenous progesterone alone or a combination 
Figure 7: Section of immature rabbit uterus treated with $1 \%$ gum acacia powder (control) (H\&E, 125x), $n=6$

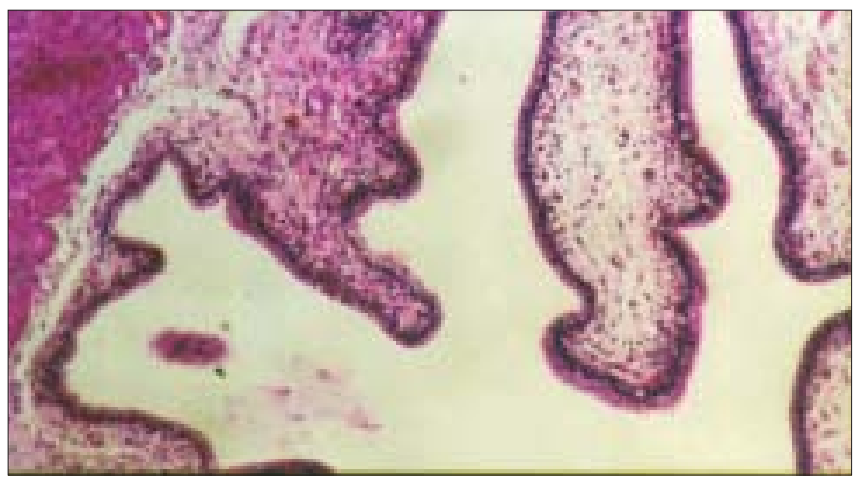

Figure 8: Section of immature rabbit uterus treated with ethanolic root extract of Momordica cymbalaria, Fenzl. (H\&E, 125x), n=6

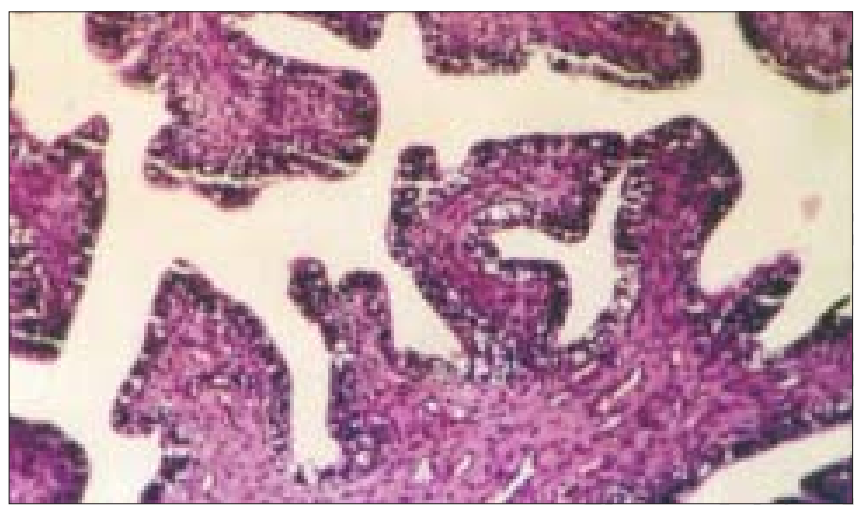

of progesterone and estrogen. In the present study, unlike the administration of estrogen and standard progesterone, administration of estrogen and the ethanolic root extract of Momordica cymbalaria Fenzl. at doses of 250 and $500 \mathrm{mg} / \mathrm{kg}$ to the ovariectomised pregnant rats did not maintain pregnancy.

Clauberg's assay is another bioassay of progestational and antiprogestational activities. ${ }^{[13]}$ The histological changes in the uterus (e.g., the endometrial proliferation) seen in estrogenpretreated immature rabbits after the administration of progestational or antiprogestational compounds are assessed here in rabbits. Progestational activity of the compound was assessed by its ability to induce endometrial proliferation (increased uterine diameter and endometrial thickness) whereas its antiprogestational activity was assessed by the ability to inhibit endometrial proliferation induced by norethisterone, a progesterone analog. Administration of estrogen alone to the rabbits caused ramification of the uterus (increased endometrial epithelial cell height), but not proliferation. In the present study, administration of both estrogen and the ethanolic root extract of Momordica cymbalaria Fenzl. at doses of 250 and $500 \mathrm{mg} / \mathrm{kg}$ showed ramification of the uterus but not proliferation, which was similar to the effect of estrogen and vehicle alone. Hence, the ethanolic root extract of Momordica cymbalaria Fenzl.
Figure 9: Section of immature rabbit uterus treated with norethisterone at the dose of $0.75 \mathrm{mg} / \mathrm{kg}(\mathrm{H} \& \mathrm{E}, 125 \mathrm{x}), \mathrm{n}=6$

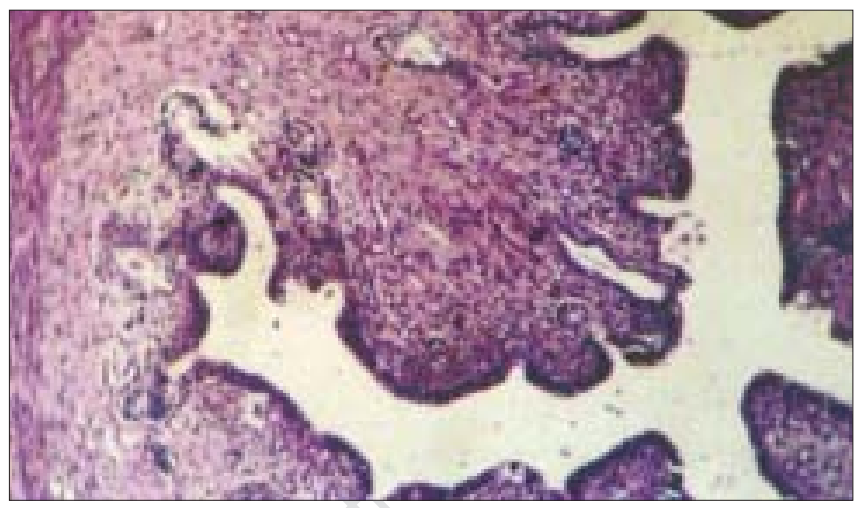

Figure 10: Section of immature rabbit uterus treated with norethisterone at the dose of $0.75 \mathrm{mg} / \mathrm{kg}$ and ethanolic root extract of Momordica cymbalaria, Fenzl at the dose of $250 \mathrm{mg} / \mathrm{kg}$ (H\&E, 125x), $\mathrm{n}=6$

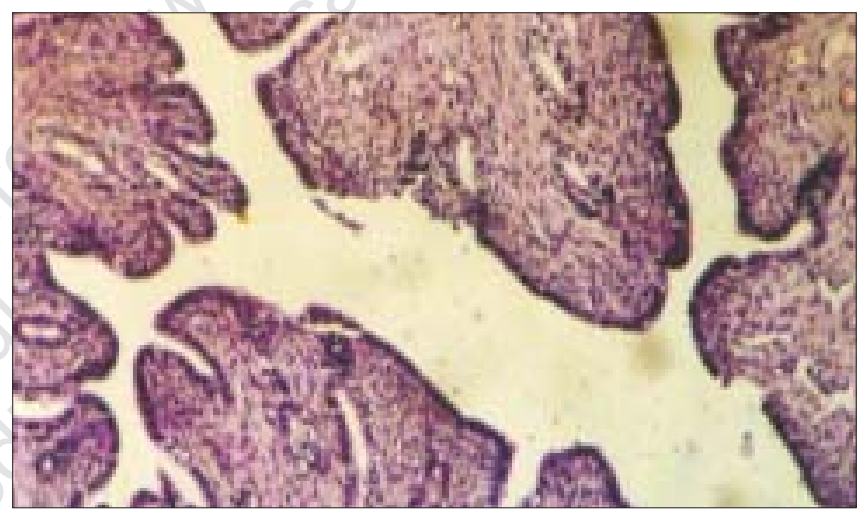

at doses of 250 and $500 \mathrm{mg} / \mathrm{kg}$ may not have progestational activity. However, further investigations are needed to understand the possible antiimplantation mechanisms of Momordica cymbalaria Fenzl.

In conclusion, the present study indicates that the ethanolic root extract of Momordica cymbalaria possesses significant postcoital antiimplantation activity in rats and it may not be due to estrogenic or progestrogenic activities.

\section{References}

1. Rao BK, Kesavulu MM, Giri R, Appa Rao C. Antidiabetic and hypolipidemic effects of Momordica cymbalaria Hook. Fruit powder in alloxan diabetic rats. J Ethnopharmacol 1999;67:103-9.

2. Rao BK, Kesavulu MM, Apparao C. Antihyperglycemic activity of Momordica cymbalaria in alloxan diabetic rats. J Ethnopharmacol 2001;78:67-71.

3. Kameswararao B, Kesavulu MM, Apparao C. Evaluation of antidiabetic effect of Momordica cymbalaria fruit in alloxan-diabetic rats. Fitotherapia 2003;74:7-13.

4. Kirtikar R, Basu BD. Indian Medicinal Plants $2^{\text {nd }}$ ed. Cucurbitaceae. Lalit Mohan Basu Publication: Allahabad; 1935. p. 1137.

5. Koneri R, Balaraman R, Saraswati CD. Antiovulatory and abortifacient potential of the ethanolic extract of roots of Momordica cymbalaria Fenzl in rats. Indian J Pharmacol 2006;38:111-4.

6. Khanna U, Garg SK, Vohra SB, Walia HB, Chaudhury RR. Antifertility screening of plants. II. Effect of six indigenous plants on early pregnancy in albino rats. Indian J Med Res 1969;57:237-44. 
7. Dennis EJ, Baker. The laboratory rat, Vol (1). Reproduction and breeding. Academic Press: New York; 1979. p. 153-68.

8. Hafez ES. Reproduction in breeding techniques for laboratory animals. Lea and Febiger: Philadelphia; 1970. p. 23-93.

9. Badmi S, Aneesh R, Sankar S, Sathishkumar MN, Suresh B, Rajan S. Antifertility activity of Derris brevipes variety coriacea. J Ethnopharmacol 2003;84:99-104.

10. Vogel HG, Wolfgang. Drug discovery and evaluation pharmacological assays. $2^{\text {nd }}$ ed. Heidelberg Publications: Springer Verlag Berlin; 1997. p. 1167-70.

11. Schmidt $H$. Effect of papain on different phases of prenatal ontogenesis in rats. Reprod Toxicol 1995;9:49-55.

12. Vohora SB, Garg SK, Chaudhury RR. Antifertility screening of plants 3. Effect of six indigenous plants on early pregnancy in albino rats. Indian J Med Res 1969;57:893-9.

13. Gebrie E, Makonnen E, Zerihun L, Debella A. The possible mechanisms for the antifertility actions of the methanolic root extract of Rumex steudelii. Afr Health
Sci 2005;5:119-25.

14. Rifai N, John J, Albers Paul SB. Fundamentals of clinical chemistry, $5^{\text {th }}$ ed. Lipids, lipoproteins and apolipoproteins. WB Saunders Company: Philadelphia; 2001. p. 462-93.

15. Dhar SK. Antifertility activity and hormonal profile of Trans-Anethole in rats. Indian J Physiol Pharmacol 1995;39:63-7.

16. Kuhnz W, Beier S. Comparative progestational and androgenic activity of norgestimate and levonorgestrel in the rat. Contraception 1994;49:275-89.

17. Tuba Z, Bardin CW, Danesi A, Francsics-Cziege E, Molnar C, Csorgei J, et al. Synthesis and biological activity of a new progestogen, 16-methylene-17alpha-hydroxy18-methyl-19-norpregn-4-ene-3, 20-doine acetate. Steroids 2000;65:266-74.

18. McKim JM Jr, Wilga PC, Breslin WJ, Plotzke KP, Gallavan RH, Meeks RG. Potential estrogenic and antiestrogenic activity of the cyclic siloxane octamethylcyclotetrasiloxane (D4) and the linear siloxane Hexamethyldisiloxane (HMDS) in immature rats using the uterotrophic assay. Toxicol Sci 2001;63:37-46. 